\title{
Pemanfaatan Air Sungai dan Infeksi Schistosoma Japonicum di Napu Poso Sulawesi Tengah Tahun 2006
}

\author{
M. Edy Hariyanto*
}

\begin{abstract}
Abstrak
Penyakit schistosomiasis menempati rengking ke dua setelah malaria sebagai masalah sosial ekonomi dan kesehatan masyarakat di daerah tropis dan sub tropis. Prevalensi Schistosomiasis di Napu pada tahun 2004 (1,71\%) masih tinggi dan cenderung meningkat. Hal tersebut didiukung oleh infection rate pada keong sebagai host intermediet yang tinggi (16.3\%) yang menunjukkan bahwa penularan masih terus terjadi. Tujuan penelitian ini adalah mengetahui hubungan pemanfaatan air sungai/ parit dengan infeksi Schistosoma japonicum di Napu Poso Sulawesi Tengah. Penelitian dengan disain studi kasus kontrol ini menggunakan sumber data sekunder hasil survey tinja dan pengamatan dengan metode Katto Katz di Napu tahun 2006. Kasus adalah responden dengan tinja yang mengandung telur cacing Schistosoma menurut, sedangkan control adalah responden dengan tinja yang tidak ditemukan telur cacing Schistosoma. Metoda analisis yang digunakan adalah regresi logistik ganda dengan ukuran asosiasi Odd Rasio dan uji Kai Kuadrat. Penelitian ini menemukan Hubungan antara perilaku pemanfaatan air sungai/parit dengan infeksi Schistosoma japonicum setelah disesuaikan terhadap perancu yaitu penggunaan sepatu boot dan pemanfaatan jamban OR=2,31 (95\% Cl : 1,22-4,36).
\end{abstract}

Kata kunci: Perilaku, air sungai, schistosomiasis

\begin{abstract}
Schistosomiasis occupies second rank after malaria as soacial-economic and public health problem in tropical and sub-tropical areas. In 2004, Schistosomiasis prevalence in Napu is considered high at $1.71 \%$ and tends to increase. This is supported by high infection rate at snail as intermediate host $(16.3 \%)$. In general, one who infected by Schistosoma is those with habit related to the use of river water. The objective of this research is to know the relationship between risk factor of the use of river water/ditch with infection of Schistosoma japonicum in Napu, Poso, Central Sulawesi province. The source of data used in this study is survey of Schistosoma using Katto Katz method in Napu in the year 2006. Cases are respondents whose faeces contained Schistosoma egg while controls are those whose faeces did not contain Schistosoma egg. The result shows positive correlation between behavior of using river water/ditch with infection of Schistosoma japonicum after confounder control with $\mathrm{OR}=2,31(95 \% \mathrm{Cl}: 1,22-4,36)$.
\end{abstract}

Key words: Behavior, river water, and schistosomiasis.

*Staf Subdin P2PL Dinas Kesehatan Kabupaten Poso 
Schistosomiasis adalah penyakit menular kronis yang disebabkan oleh cacing trematoda dari genus Schistosoma termasuk waterborne parasitic disease. Cacing tersebut hidup di dalam pembuluh darah vena manusia dan binatang mamalia. Infeksi terjadi melalui kontak dengan air tawar yang terkontaminasi serkaria yang masuk ke dalam tubuh melalui kulit. Serkaria tersebut mengikuti aliran darah dan menjadi dewasa di vena porta hepatica atau vena mesenterika. Cacing jantan dan betina yang selalu bersatu menembus dinding usus untuk bertelur. Sebagian telur akan mengikuti aliran darah ke hati dan terjebak dalam hati sehingga terjadi sirosis dan sebagian lainnya keluar bersama tinja.1,2 Siklus hidup cacing Schistosoma memerlukan hospes perantara keong Oncomelania hupenis lindoensis yang hidup di daerah basah seperti rawa, sungai, parit, sawah, hutan dan rembesan air. ${ }^{3}$ Hubungan erat antara manusia, hewan reservoir dengan habitat keong dan perilaku buang air besar di sembarang tempat, menyebabkan penularan terjadi secara terus menerus. Selain itu, frekuensi kontak habitat keong menyebabkan peningkatan jumlah penderita. Selain manusia, Schistosomiasis juga menyerang hewan mamalia seperti; kambing, anjing, kucing, lembu, kerbau, tikus, rusa, babi hutan, luwak, cecurut, dan kuda.4,5

Di seluruh dunia, lebih dari 200 juta orang menderita Schistosomiasis, 20 juta diantaranya menderita sakit berat, dan 120 juta menunjukkan tanda-tanda klinis. Serta menjadi ancaman bagi 500-600 juta orang di 74 negara berkembang. ${ }^{6}$ Schitosomiasis tersebar di seluruh dunia meliputi negara-negara Asia, Afrika, Amerika Latin dan Timur Tengah. Di Asia, cacing ini tersebar di tujuh negara, antara lain Jepang, Cina, Philipina, Indonesia, Malaysia, Kamboja, Laos dan Thailand. Di Asia penyakit ini umumnya disebabkan oleh cacing Schistosoma japonicum.

Di Indonesia penyakit ini baru ditemukan di lembah Lindu (Kec. Kulawi, Kab. Donggala) dan lembah NapuBesoa (Kec. Lore Utara, Kab. Poso), keduanya terletak di Sulawesi Tengah. Schistosomiasis masih menjadi ancaman bagi lebih dari 25.000 penduduk di kedua daerah endemis tersebut. Prevalensi Schistosomiasis di lembah Lindu pada tahun $2003(0.64 \%)$ dan tahun 2004 $(0,17 \%)$ memperlihatkan kecenderungan yang menurun. Sementara di lembah Napu pada tahun 2003 $(0.70 \%)$ dan tahun $2004(1,71 \%)$ memperlihatkan kecenderungan yang meningkat. Kondisi yang berfluktuasi ini akan semakin meningkat dan meluas sehubungan dengan migrasi penduduk, pembangunan, perkembangan ekonomi dan perdagangan khususnya daging mamalia yang menjadi hospes reservoir. Kemajuan pembangunan yang membuka daerah endemik Schistosomiasis yang dahulunya terisolasi.

Setelah 25 tahun upaya pemberantasan telah dilakukan secara intensif, tetapi prevalensi Schistosomiasis pada manusia berhasil diturunkan, tetapi belum juga terelimininasi. Tujuan penelitian ini adalah mengetahui hubungan antara pemanfaatan air sungai/parit dengan infeksi Schistosoma japonicum.

\section{Metode}

Penelitian yang dilakukan wilayah Puskesmas Napu Kecamatan Lore Utara Kabupaten Poso Sulawesi Tengah ini menggunakan rancangan studi kasus kontrol yang merupakan studi analitik observasional. Desain ini dipilih karena kasus yang diteliti jarang terjadi dan tujuan penelitian menilai berbagai faktor risiko yang diamati. Penelitian dilaksanakan pada bulan Juni s/d Juli 2006 dengan menggunakan sumber data primer yang dikumpulkan melalui wawancara terstruktur baik terhadap kasus maupun kontrol. Populasi adalah anggota keluarga yang berpartisipasi dalam survei tinja tahun 2006 dan tinggal di wilayah kerja Puskesmas Napu. Subjek penelitian adalah individu yang telah di periksa dalam survei tinja dan pengamatan siklus pertama (Januari s/d Juni). Kasus adalah subjek penelitian yang pada pemeriksaan tinja ditemukan telur cacing Schistosoma japonicum. Kontrol adalah subjek penelitian yang tidak ditemukan cacing Schistosoma japonicum dalam tinja mereka. Kriteria eksklusi meliputi umur $<10$ tahun, dengan tanda-tanda Schistosomiasis kronis, mengalami gangguan jiwa dan telah meninggal dunia pada saat penelitian berlangsung.

Besar sampel dihitung dengan menggunakan rumus perhitungan besar sampel untuk kasus kontrol. ${ }^{7}$ Dengan nilai $\alpha=5 \% ; \beta=20 \%$, proporsi kontrol yang terpajan dengan pajanan yang diteliti 0,469 dan perkiraan odds ratio berdasarkan hasil penelitian terdahulu 2,29.8 Dengan menggunakan rumus perhitungan besar sampel untuk kasus kontrol didapatkan jumlah sampel minimal $95 .{ }^{7}$ Jumlah kasus yang didapatkan ternyata tidak mencapai jumlah sampel minimal untuk kasus (65 kasus). maka jumlah responden dihitung ulang dengan menggandakan jumlah kontrol menjadi 1:3. Dengan demikian jumlah kasus dan kontrol yang diteliti adalah 65 : 195, jumlah sampel seluruhnya menjadi 260 orang.

Analisis data yang dilakukan secara bertahap meliputi analisis univariat, bivariat dan multivariat. Analisis univariat dilakukan untuk membandingkan distribusi responden berdasarkan berbagai variabel independen pada kelompok kasus dan kontrol guna menilai variabel perancu potensial. Analisis Bivariat, digunakan mengidentifikasi variabel perancu dengan menggunakan uji t-test untuk variabel numerik dan uji Chi-Square $\left(\chi^{2}\right)$ untuk variabel kategorik. Keeratan hubungan dinilai dengan ukuran Odds Ratio (OR). Analisis Multivariat digunakan untuk menilai keeratan hubungan antara variabel dependen dengan variabel 
independen secara simultan dalam populasi. Metoda analisis multivariat yang digunakan adalah unconditional logistic regression, dengan pendekatan model etiologi.

\section{Hasil}

Rata-rata umur pada kelompok kasus (39,5 tahun) adalah lebih tua daripada kontrol (33,6 tahun). Distribusi berdasarkan tingkat pendidikan ditemukan sebagian besar adalah tamat SD. Pada kelompok kasus $(49,23 \%)$ relatif lebih rendah dari pada kelompok kontrol $(57,44 \%)$, Sebagian besar pekerjaan responden adalah petani pada kelompok kasus $(78,46 \%)$ lebih besar daripada kelompok kontrol $(57,44 \%)$. Sedang distribusi responden berdasarkan status gizi pada umumnya adalah normal, baik pada kasus $(67,69 \%)$ relatif lebih tinggi kontrol $(59,49 \%)$.

Proporsi yang memanfaatkan air sungai/parit pada kasus adalah 64,62\%, sedang proporsi yang memanfaatkan air sungai/parit pada kontrol adalah $36,92 \%$.

Dari hasil analisis bivariat ditemukan variabel independen yang memenuhi kriteria kandidat model adalah pememanfaatan air (nilai $\mathrm{p}=0,000$ ); umur (nilai $\mathrm{p}=0,113$ ); pekerjaan (nilai $\mathrm{p}=0,001$ ); status gizi (nilai $p=0,222$ ); pengetahuan (nilai $p<0,05$ ); penggunaan sepatu boot (nilai $\mathrm{p}=0,013$ ); pemanfaatan jamban (nilai $\mathrm{p}=0,001$ ); ketersediaan air bersih (nilai $\mathrm{p}=0,082$ ) (Lihat pada tabel 2 dan tabel 3).

Model akhir multivariat terdapat hubungan antara pemanfaatan air sungai/parit dengan infeksi Schistosoma japonicum, dan ditemukan 2 variabel confounder yaitu penggunaan sepatu boot dan pemanfaatan jamban. Terlihat bahwa pemanfaatan air sungai/parit berhubungan secara bermakna dengan infeksi Schistosoma japonicum. Subjek penelitian yang memanfaatkan air sungai/parit berisiko terinfeksi Schistosoma japonicum 2,31 kali lebih besar daripada dibanding yang tidak memanfaatkan air sungai/parit setelah dilakukan pengendalian terhadap faktor perancu penggunaan sepatu boot dan pemanfaatan jamban $(95 \% \mathrm{CI}: 1,22-4,36)$. (Lihat Tabel 4)

\section{Pembahasan \\ Kelemahan Penelitian}

Beberapa kelemahan yang mungkin ditemukan adalah bias seleksi, bias informasi dan bias mengingat kembali. Pada penelitian ini, bias seleksi dikendalikan dengan cara memilih kelompok kontrol dari populasi tempat kelompok kasus berasal. Kasus dan kontrol sama-sama ditentukan berdasarkan hasil pemeriksaan laboratorium. Kasus dan kontrol diambil dari wilayah Napu Poso Sulawesi Tengah, terdiri dari responden survei tinja pemeriksaan schistosomiasis. Bias misklasifikasi, mungkin terjadi akibat kesalahan diagnosis, seperti positif palsu pada kasus dan negatif palsu pada kontrol. Positif palsu dapat terjadi karena kesalahan pembuatan slide pemeriksaan, sedang negatif palsu karena kesalahan pemeriksaan, dan pengumpulan sampel tinja dilakukan pada masa pre-patent Schistosoma japonicum dalam periode 6-10 minggu setelah infeksi. Pada poenelitian ini kemungkinan terjadi negatif palsu yang menyebabkan bias mendekati nul.

Bias mengingat kembali (recall bias) dapat terjadi akibat responden lupa tentang pajanan yang diamati. Tingkat akurasi dalam mengingat kembali riwayat pajanan penyakit yang sedang diteliti berbeda untuk setiap responden. Untuk meminimalisasi recall bias pada penelitian ini, sampel diambil dari hasil pemeriksaan survei tinja penduduk pada siklus pertama yang berakhir pada bulan Juni 2006. Diharapkan pajanan yang terjadi pada tiga bulan terakhir masih dapat diingat dengan baik. Selain itu, dilakukan latihan pewawancara tentang cara menggali informasi dari responden dengan harapan dapat memberikan pemahaman maksud setiap pertanyaan dalam kuesioner, sehingga dapat memperkecil recall bias yang mungkin terjadi. Bias pewawancara dapat terjadi khususnya pada variabel pengetahuan responden, akibat perbedaan kualifikasi dan kreativitas dalam mengembangkan pertanyaan untuk tujuan yang sama. Untuk itu, pewawancara dipilih dengan kriteria minimal tamat SMA.

Faktor perancu dapat menyebabkan distorsi penaksiran terhadap faktor risiko yang sedang diteliti sehingga menyebabkan odds ratio yang diteliti tidak menggambarkan nilai odds ratio yang sebenarnya, bisa memperkecil atau memperbesar. Pada penelitian ini usaha mengendalikan pengaruh faktor perancu dilakukan dengan analisis multivariat.

Penelitian ini menemukan hubungan yang bermakna antara pemanfaatan air sungai/parit dengan infeksi Schistosoma japonicum, setelah dikendalikan variabel perancu. Hasil penelitian ini sesuai dengan hasil beberapa penelitian terdahulu. Penelitian di Nigeria menemukan kontak dengan air berhubungan dengan infeksi schistosomiasis $(\mathrm{r}=0,97) .{ }^{9}$ Penelitian di Kafr ElSheikh Mesir menemukan perilaku mandi di sungai berisiko lebih besar terinfeksi Schistosoma mansoni $(\mathrm{OR}=3,45)$, mencuci $(\mathrm{OR}=3,09)$, dan bermain untuk anak-anak umur $<15$ th $(\mathrm{OR}=3,74) .{ }^{8}$ Penelitian di 4 provinsi di Mesir, menemukan perilaku berisiko tinggi terinfeksi Schistosoma mansoni adalah mandi di saluran air $(\mathrm{OR}=2,84)$, mencuci $(\mathrm{OR}=2,29)$, dan bermain bagi anak-anak umur $<15$ th $(\mathrm{OR}=2,76) .{ }^{10}$ Berbagai penelitian tersebut lebih terarah pada faktor risiko infeksi Schistosoma mansoni yang dinilai sendiri-sendiri. Pada penelitian ini, lebih ditekankan pada faktor risiko pemanfaatan air sungai/parit dengan infeksi Schistosoma japonicum dengan mengendalikan bias perancu. 
Tabel 1. Hasil Analisis Bivariat Variabel Utama dan Kovariat terhadap Infeksi Schistosoma Japonicum di Napu Sulawesi Tengah Tahun 2006

\begin{tabular}{|c|c|c|c|c|c|c|c|}
\hline \multirow[t]{2}{*}{ Faktor Risiko } & \multicolumn{2}{|c|}{ Kasus $(n=65)$} & \multicolumn{2}{|c|}{ Kontrol $(n=195)$} & \multirow[t]{2}{*}{ OR } & \multirow[t]{2}{*}{$95 \% \mathbf{C I}$} & \multirow[t]{2}{*}{ Nilai-p } \\
\hline & $\mathbf{n}$ & $\%$ & $\mathrm{n}$ & $\%$ & & & \\
\hline \multicolumn{8}{|l|}{ Variabel Utama } \\
\hline \multicolumn{8}{|l|}{ Pemanfaatan Air Sungai/parit } \\
\hline Memanfaatkan sal. air/parit & 42 & 64,62 & 72 & 36,92 & 3,12 & $1,73-5,60$ & 0,000 \\
\hline Tidak memanfaatkan sal air/parit & 23 & 35,38 & 123 & 63,08 & 1 & & \\
\hline \multicolumn{8}{|l|}{ Variabel Kovariat } \\
\hline \multicolumn{8}{|l|}{ Umur } \\
\hline Berisiko & 58 & 89,23 & 157 & 80,51 & 2,01 & $0,85-4,74$ & 0,113 \\
\hline Kurang Berisiko & 7 & 10,77 & 38 & 19,49 & 1 & & \\
\hline \multicolumn{8}{|l|}{ Pendidikan } \\
\hline Rendah (SMP ke bawah) & 58 & 89,23 & 172 & 88,21 & 0,90 & $0,37-2,21$ & 0,823 \\
\hline Tinggi (SMA ke atas) & 7 & 10,77 & 23 & 11,79 & 1 & & \\
\hline Rendah (SD ke bawah) & 42 & 64,62 & 123 & 63,08 & 1,07 & $0,59-1,92$ & 0,823 \\
\hline Tinggi (SMP ke atas) & 23 & 35,38 & 72 & 36,92 & 1 & & \\
\hline \multicolumn{8}{|l|}{ Pekerjaan } \\
\hline Berisiko (IRT) & 51 & 78,46 & 108 & 55,38 & 2,93 & $1,52-5,65$ & 0,001 \\
\hline Kurang Berisiko & 14 & 21,54 & 87 & 44,62 & 1 & & \\
\hline \multicolumn{8}{|l|}{ Status Gizi } \\
\hline Kurang & 13 & 20,00 & 54 & 27,69 & 0,65 & $0,33-1,29$ & 0,222 \\
\hline Baik & 52 & 80,00 & 141 & 72,31 & 1 & & \\
\hline
\end{tabular}

Tabel 2. Hasil Analisis Bivariat Faktor Risiko Pengetahuan terhadap Infeksi Schistosoma Japonicum di Napu Sulawesi Tengah Tahun 2006

\begin{tabular}{|c|c|c|c|c|c|c|c|}
\hline \multirow[t]{2}{*}{ Faktor Risiko } & \multicolumn{2}{|c|}{ Kasus $(n=65)$} & \multicolumn{2}{|c|}{ Kontrol $(n=195)$} & \multirow[t]{2}{*}{ OR } & \multirow[t]{2}{*}{$95 \%$ CI } & \multirow[t]{2}{*}{ Nilai-p } \\
\hline & $\mathbf{n}$ & $\%$ & $\mathbf{n}$ & $\%$ & & & \\
\hline \multicolumn{8}{|c|}{ Pengetahuan gejala penyakit } \\
\hline Pengetahuan salah & 40 & 61,54 & 101 & 51,79 & 1,49 & $0,84-2,64$ & 0,173 \\
\hline Pengetahuan benar & 25 & 38,46 & 94 & 48,21 & 1 & & \\
\hline \multicolumn{8}{|c|}{ Pengetahuan penyebab penyakit } \\
\hline Pengetahuan salah & 23 & 35,38 & 75 & 38,46 & 0,88 & $0,49-1,57$ & 0,658 \\
\hline Pengetahuan benar & 42 & 64,62 & 120 & 61,54 & 1 & & \\
\hline \multicolumn{8}{|c|}{ Pengetahuan cara penularan } \\
\hline Pengetahuan salah & 16 & 24,62 & 49 & 25,13 & 0,97 & $0,51-1,86$ & 0,934 \\
\hline Pengetahuan benar & 49 & 75,38 & 146 & 74,87 & 1 & & \\
\hline \multicolumn{8}{|c|}{ Pengetahuan tempat penularan } \\
\hline Pengetahuan salah & 28 & 43,08 & 83 & 42,56 & 1,02 & $0,57-1,80$ & 0,942 \\
\hline Pengetahuan benar & 37 & 56,92 & 112 & 57,44 & 1 & & \\
\hline \multicolumn{8}{|c|}{ Pengetahuan bahaya penyakit } \\
\hline Pengetahuan salah & 15 & 23,08 & 52 & 26,67 & 0,83 & $0,43-1,59$ & 0,567 \\
\hline Pengetahuan benar & 50 & 76,92 & 143 & 73,33 & 1 & & \\
\hline \multicolumn{8}{|c|}{ Pengetahuan cara pencegahan } \\
\hline Pengetahuan salah & 7 & 10,77 & 40 & 20,51 & 0,47 & $0,20-1,10$ & 0,082 \\
\hline Pengetahuan benar & 58 & 89,23 & 155 & 79,49 & 1 & & \\
\hline \multicolumn{8}{|c|}{ Pengetahuan pengobatan penyakit } \\
\hline Pengetahuan salah & 8 & 12,31 & 37 & 18,97 & 0,60 & $0,26-1,36$ & 0,222 \\
\hline Pengetahuan benar & 57 & 87,69 & 158 & 81,03 & 1 & & \\
\hline \multicolumn{8}{|c|}{ Pengetahuan pemberantasan } \\
\hline Pengetahuan salah & 11 & 16,92 & 36 & 18,46 & 0,90 & $0,42-1,89$ & 0,780 \\
\hline Pengetahuan benar & 54 & 83,08 & 159 & 81,54 & 1 & & \\
\hline \multicolumn{8}{|l|}{ Tingkat pengetahuan } \\
\hline Pengetahuan salah & 24 & 36,92 & 62 & 31,79 & 1,26 & $0,70-2,26$ & 0,447 \\
\hline Pengetahuan benar & 41 & 63,08 & 133 & 168,21 & 1 & & \\
\hline
\end{tabular}


Tabel 3. Hasil Analisis Bivariat Hubungan Faktor Penggunaan Sepatu Boot, Pemanfaatan Jamban dan Ketersediaan Air Bersih dengan Infeksi Schistosoma Japonicum di Napu Sulawesi Tengah Tahun 2006

\begin{tabular}{|c|c|c|c|c|c|c|c|}
\hline \multirow[t]{2}{*}{ Faktor Risiko } & \multicolumn{2}{|c|}{ Kasus $(n=65)$} & \multicolumn{2}{|c|}{ Kontrol $(n=1955)$} & \multirow[t]{2}{*}{ OR } & \multirow[t]{2}{*}{ 95\% CI } & \multirow[t]{2}{*}{ Nilai-p } \\
\hline & $\mathbf{n}$ & $\%$ & $\mathbf{n}$ & $\%$ & & & \\
\hline \multicolumn{8}{|c|}{ Penggunaan sepatu boot } \\
\hline Tidak memakai & 49 & 75,38 & 113 & 57,95 & 2,22 & $1,18-4,18$ & 0,013 \\
\hline Memakai & 16 & 24,62 & 82 & 42,05 & 1 & & \\
\hline \multicolumn{8}{|l|}{ Pemanfaatan jamban } \\
\hline Tidak memanfaatkan & 20 & 30,77 & 23 & 11,79 & 3,32 & $1,57-6,94$ & 0,001 \\
\hline Memanfaatkan & 45 & 69,23 & 172 & 88,21 & 1 & & \\
\hline \multicolumn{8}{|l|}{ Keterediaan air Bersih } \\
\hline Tidak tersedia & 7 & 10,77 & 9 & 4,62 & 2,49 & $0,70-6,99$ & 0,082 \\
\hline Tersedia & 58 & 89,23 & 186 & 95,38 & 1 & & \\
\hline
\end{tabular}

Tabel 4. Model Akhir Regresi Logistik Hubungan Pemanfaatan Air Sungai/parit dengan Infeksi Schistosoma Japonicum di Napu Sulawesi Tengah Tahun 2006

\begin{tabular}{lcccc}
\hline Faktor Risiko & Koefisien & OR & 95\% CI & Nilai-p \\
\hline Pemanfaatan air sungai & 0,837 & 2,31 & $1,22-4,36$ & 0,010 \\
Penggunaan Sepatu boot & 0,573 & 1,71 & $0,92-3,42$ & 0,088 \\
Pemanfaatan jamban & 0,734 & 1,94 & $0,99-4,37$ & 0,052 \\
Konstanta & $-2,055$ & & & \\
\hline
\end{tabular}

Long likehood $=-134.94007$

Persamaan dengan hasil penelitian terletak pada pajanan kontak dengan air yang mengandung serkaria. Mekanisme penularan schistosomiasis terkait sangat erat dengan air. Berbagai penelitian yang dilaksanakan di tempat berbeda dan terhadap jenis schistosoma yang berbeda, namun mekanisme penularan semua jenis schistosomiasis tersebut adalah sama.

Upaya pemberantasan schistosomiasis yang dilaksanakan oleh sektor kesehatan saat ini terfokus pada upaya pengamatan dan pengobatan. Kegiatan tersebut meliputi; survei tinja pada seluruh penduduk, survei keong/daerah fokus, survei tikus dan pengobatan selektif. Upaya ini tidak akan menyelesaikan seluruh masalah schistosomiasis. Pengobatan dapat menyembuhkan schistosomiasis, tetapi jika perilaku masyarakat tidak berubah, maka penularan schistosomiasis akan terus terjadi. Dengan demikian, berbagai upaya pencerahan pada masyarakat khususnya tentang faktor risiko schistosomiasis tetap diperlukan. Upaya-upaya penyuluhan tersebut perlu terus dilakukan dan dikembangkan agar lebih menarik.

Upaya-upaya pemberantasan tersebut perlu diimbangi dengan ketersediaan sarana air bersih yang cukup dan bebas dari serkaria, sehingga masyarakat tidak lagi memanfaatkan air sungai/parit untuk keperluan keluarganya. Sarana-sarana air bersih yang ada saat ini masih sangat rentan terhadap kontaminasi serkaria, sehingga perlu adanya pengolahan air yang dapat membunuh serkaria, cara yang simpel dan mudah dilakukan adalah membiarkan air selama 24 - 48 jam sebelum digunakan, hal ini terkait dengan kemampuan hidup serkaria. Untuk membangun sarana pengolahan air bersih tersebut sangat diperlukan peran sektor terkait dalam hal ini Kimpraswil, upaya alternatifnya adalah membangun bak-bak penampung air/bak pengendap dengan sistim buka tutup yang memungkinkan air dapat tertampung selama 24 - 48 jam sebelum di distribusikan ke rumahrumah.

Pada penelitian ini tidak ditemukan hubungan yang bermakna antara kelompok umur dengan infeksi Schistosoma japonicum. Hasil penelitian ini berbeda dengan penelitian di provinsi Karl El-Sheikh Mesir yang menemukan umur berhubungan dengan infeksi Schistosoma manson. Kelompok yang berisiko paling tinggi terinfeksi Schistosomiasis di Indonesia $(\mathrm{OR}=$ 4,47 dan Brazil $(\mathrm{OR}=4,47)$ adalah umur $10-20$ tahun. ${ }^{8}, 11$ Ada beberapa kemungkinan yang dapat dijelaskan sehubungan dengan hasil penelitian ini. Pertama, karakteristik populasi pada penelitian ini berbeda dengan penelitin lain. Kedua perbedaan penarikan sampel kelompok umur. Pada penelitian sebelumnya, yang diteliti adalah semua kelompok umur dan kelompok umur 0 - 10 tahun dijadikan pembanding. Pada penelitian ini, responden yang diteliti berumur 10 tahun ke atas dan kelompok umur 10-19 tahun dijadikan pembanding. Diasumsikan bahwa kelompok umur tersebut 
merupakan usia sekolah yang berisiko relatif rendah terhadap infeksi Schistosoma japonicum.

Pada penelitian ini, pendidikan yang dikategorikan menjadi pendidikan tinggi (SMA keatas) dan pendidikan rendah (SMP kebawah) terlihat tidak berhubungan secara bermakna infeksi Schistosoma japonicum. Hasil yang sama juga ditemukan jika kategori pendidikan rendah adalah tamat SD kebawah. Hasil penelitian ini tidak sejalan dengan penelitian di Brazil yang menyimpulkan bahwa pendidikan memiliki hubungan bermakna dengan infeksi Schistosoma mansoni $(\mathrm{p}=0,005) .{ }^{11}$ Perbedaan ini terjadi diduga karena pada penelitian ini kelompok tingkat pendidikan rendah memiliki proporsi yang jauh lebih besar, baik pada kasus maupun pada kontrol sehingga variasinya tidak terlalu jauh berbeda. Selain itu, tidak selalu mereka yang berpendidikan tinggi akan memiliki tingkat pengetahuan kesehatan dan perilaku kesehatan yang baik pula.

Petani berisiko terinfeksi Schistosoma japonicum tiga kali lebih besar daripada bukan petani. Aktivitas mereka berisiko tinggi untuk kontak dengan air yang terinfeksi (fokus keong). Keadaan tanah yang berlumpur seperti sawah merupakan media alami bagi perkembangan alga sebagai makanan keong. ${ }^{4}$ Selain itu, kebiasaan petani membersihkan peralatan, mencuci kaki, tangan di saluran air/parit setelah bekerja dapat menyebabkan infeksi. Penelitian ini sesuai dengan penelitian sebelumnya yang menemukan bahwa petani berhubungan secara bermakna dengan infeksi Schistosoma mansoni. ${ }^{12,13}$ Penelitian ini juga menemukan penggunaan sepatu boot berperan sebagai faktor perancu. Responden yang tidak menggunakan sepatu boot berisiko terinfeksi Schistosoma japonicum 2,22 kali lebih besar daripada yang menggunakan sepatu boot.Hasil penelitian mendukung teori mekanisme penularan schistosomiasis yang dapat terjadi melalui kontak langsung dengan air yang tercemar serkaria yang melakukan penetrasi pada kulit yang tidak terlindungi.

Dari hasil analisis multivariat diketahui bahwa pemanfaatan jamban merupakan faktor perancu hubungan pemanfaatan air sungai/parit dengan infeksi schistosoma japonicum. Responden yang tidak memanfaatkan jamban berisiko terinfeksi Schistosoma japonicum tiga setengah kali lebih besar daripada yang memanfaatkan jamban. Hasil ini sesuai dengan penelitian yang menemukan bahwa pemanfaatan jamban yang tidak baik berisiko terinfeksi Schistosoma japonicum 6,66 kali lebih besar daripada yang memanfaatkan jamban dengan baik. ${ }^{13}$ Umumnya, masyarakat Napu yang memanfaatkan sungai/ parit, semak-semak sebagai tempat buang air besar dapat menyebabkan siklus penularan terus terjadi, karena telur yang keluar bersama tinja akan menetas menjadi miracidium dan memiliki potensi menemukan keong perantara.

Penelitian ini memperlihatkan hubungan yang tidak bermakna antara ketersediaan sarana air bersih dengan infeksi Schistosoma japonicum. Hasil penelitian ini berbeda dengan penelitian yang menemukan sarana air bersih merupakan faktor risiko reinfeksi Schistosoma japonicum. ${ }^{13}$ Sarana air bersih yang tidak baik berisiko terinfeksi Schistosoma japonicum 7,87 kali lebih besar daripada sarana air bersih yang baik. Beda tersebut diduga disebabkan oleh proporsi kelompok kasus dan kontrol yang tidak memiliki sarana air bersih pada penelitian ini sama besar. Penelitian ini, lebih menekankan pada ketersediaan sarana air bersih, sedang penelitian Sibadu lebih pada pemanfaatan sarana air bersih. Anggota masyarakat yang tidak memiliki sarana air bersih, akan menggunakan sarana air bersih milik tetangga. Kultur masyarakat pedesaan yang saling tolong menolong, cenderung tetap memanfaatkan air bersih untuk keperluan sehari-hari.

\section{Kesimpulan}

Dari hasil penelitian dapat disimpulkan bahwa: Perilaku pemanfaatan air sungai/parit memiliki risiko terinfeksi Schistosoma japonicum 2,31 kali dibanding perilaku yang tidak memanfaatkan air sungai/parit setelah dilakukan pengontrolan terhadap bias akibat faktor perancu (confounding) yaitu penggunaan sepatu boot dan pemanfaatan jamban $(95 \% \mathrm{CI}: 1,22-4,36)$.

\section{Saran}

1. Untuk penduduk, disarankan tidak menggunakan air sungai/ parit untuk mandi, mencuci, buang air besar atau bermain. Air untuk keperluan keluarga hendaknya diambil dari sumber yang bebas serkaria.

2. Untuk Dinas Kesehatan, disarankan untuk terus melakukan penyuluhan kepada masyarakat dengan metode yang lebih menarik, khususnya pada kelompok yang paling berisiko. Pemberantasan (fokus keong) yang berada di sekitar lingkungan pemukiman perlu terus dilakukan. Berbagai kegiatan rutin seperti survey tinja, keong dan tikus, serta pengobatan disaranka untuk terus dilakukan.

3. Untuk sektor pemukiman dan prasarana wilayah disarankan untuk membangun sarana pengolahan air yang melengkapi perpipaan yang sudah ada dengan membuat bak-bak penampung air/bak pengendap.

4. Untuk sektor pendidikan nasional, disarankan untuk memasukkan mata pelajaran di sekolah-sekolah sebagai mata pelajaran muatan lokal yang terfokus pada pengetahuan tentang gejala penyakit, penyebab penyakit dan tempat penularan schistosomiasis.

5. Untuk PKK, disarankan untuk menyebarluaskan informasi dan penyuluhan penyakit schistosomiasis kepada masyarakat, sebagai motivator peran serta 
masyarakat pada pengumpulan tinja dan pengobatan dalam rangka pemberantasan schistosomiasis.

6. Untuk peneliti disarankan meneliti lebih lanjut dengan memperbaiki metode diagnosisnya seperti penggunaan urine precipitin test (UPT) yang lebih sensitif dalam mendiagnosis schistosomiasis. Juga perlu penelitian lebih lanjut tentang pemberantasan yang efektif dalam menurunkan prevalensi Schistosomiasis.

\section{Daftar Pustaka}

1. Ross, Allen G.P., at.all., 2002. Schistosomiasis, Journal of Medicine, Volume 346 (8):1212-1220.

2. Bierman, Wouter FW., Wetsteyn, Jose CFM., Van Gool, Tom., 2005. Presentation and Diagnosis of Imported Schistosomiasis : Relevance of Eosinophilia, Microscopy for Ova, and Serology, J. Travel Med, 12 : 913 (http://www.blackwell-synergy.com/doi/pdf/10.2310/7060.2005. $\underline{00003)}$

3. Izhar, A., Sinaga, R.M., Sudomo, M., Wardiyo, N.D., 2002. Recent Situation of Schistosomiasis in Indonesia, Acta Tropica 82 : 283-288.

4. Kasnodihardjo, 1997. Masalah Sosial budaya dalam Upaya Pemberantasan Schistosomiasis di Sulawesi Tengah, Cermin Dunia Kedokteran, No. 118 Tahun $1997: 40-43$.

5. Payne, G., at all., 2006. Concurrent Comparison of Three Water Contact Measurement Tools in Four Endemic Villages of The Philippines. The Schistosomiasis Transmission Ecology in The Philippines Project (STEP). Tropical Medicine and International Health, Vol. II No. $6: 834-842$
6. World Health Organization, 1996. Schistosomiasis, Fact Sheet No 115 , WHO Geneva, akses tanggal 18/05/2006 http://www.who.ch/

7. Schesselman, James J., 1982. Case Control Studies, Design, Conduct, Analysis, Oxford University Press, New York.Kelsey, J.L., at.all., 1996. Methods in Observational Epidemiology, Second edition, Oxford University Press, New York.

8. Barakat, R., at.al., 2000. The Epidemiology Of Schistosomiasis in Egypt : Patterns of Schistosoma Mansoni Infection and Morbidity in Kafr El-Sheikh, Am. J. Trop. Med. Hyg. 62(2)S, pp. 21-27.

9. Useh, MF., Ejezie, GC., 1999. Modification of Behaviour and Attitude in The Control Schistosomiasis. 1. Observations on Water Contact Patterns and Perception of Infection. Annals of Tropical Medicine And Paracitology, Vol. 39 (7) : 711-720

10. El-Khoby, T., at.all.,2000. The Epidemiology Of Schistosomiasis in Egypt : Summary Finding in Nine Governorates, Am. J. Trop. Med. Hyg. 62(2)S, pp. 88-99.

11. Massara, Cristiano L., at all.,2004. Factors Associated with Schistosomiasis Mansoni in a Population from the Municipality of Jaboticatubas State of Minas Gerais Brazil, Mem Inst Oswaldo Cruz, Rio de Jeneiro, Vol 99(Suppl. I): 127-134.

12. Bethony, Jeffrey., at all, 2004.Exposure to Schistosoma mansoni infection in a rural area in Brazil. Part III : household aggregation of watercontact behaviour, Tropical Medicine and International Health, Vol. 9 No.3 pp:381-389 (http://www.blackwell-synergy.com/doi/pdf/10.1111 /j.1365-3156.2004.01203.x) akses tanggal 31-07-2006

13. Sibadu, Anas., 2002. Pengaruh Pekerjaan, Status Gizi, Pemanfaatan Jamban Keluarga dan Pemanfaatan Sarana Air Bersih Terhadap Reinfeksi Schistosomiasis Japonica Pasca-Terapi di Dataran Tinggi Napu Kabupaten Poso Provinsi Sulawesi Tengah Tahun 2002. Thesis, Unair Surabaya 